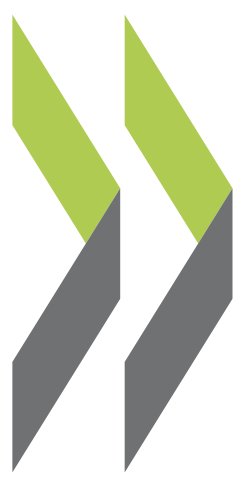

CELE Exchange, Centre for Effective Learning Environments 2010/09

\title{
Public School Revitalisation in Detroit
}

\section{Christin Cave}

https://dx.doi.org/10.1787/5kmbjxzkgxbw-en 


\section{Public school revitalisation in Detroit}

\section{By Christin Cave, consultant, OECD.}

One of the main problems facing big-city school districts in the United States is deteriorating and underutilised school infrastructure. The Detroit public school district is attempting to tackle this issue with an injection of federal funding and a comprehensive school facilities renovation plan. Money from a bond issue passed in November 2009 will be used to construct new replacement school buildings and renovate existing ones to efficiently transform the school district and the city.

Too many children and not enough schools was once the issue facing urban school districts across the United States at the turn of the twentieth century. The rise of industrialisation and the subsequent influx of workers and immigrants overwhelmed urban areas and school planners alike, with everyone demanding access to public schools. However, a shift in demographics, caused by de-industrialisation and suburbanisation, has relocated families and businesses outside of city centres, thus creating new efficiency and management pressures on public schools.

This trend has been most remarkable in the Detroit Public School system (DPS), Michigan's largest school district. In the 1920s, the city's public school system was overloaded and could not construct schools fast enough to accommodate the increasing number of students. Now, the problem in Detroit is acute, and over the past ten years alone the student population has drastically declined; its schools face high drop-out, poor academic achievement and low graduation rates. Enrolment is expected to continue to fall over the coming years as families opt for alternatives to a public school system which is perceived to be failing. Consequently, despite the closure of over 100 schools since 2004, the city will have to condense the existing stock of buildings still further to accommodate the diminishing number of students at all levels of schooling. In addition, the remaining stock of buildings in Detroit, as in many urban areas, is plagued with leaky roofs, faulty plumbing, outdated resources and poor heating and cooling systems due to negligence and insufficient maintenance.

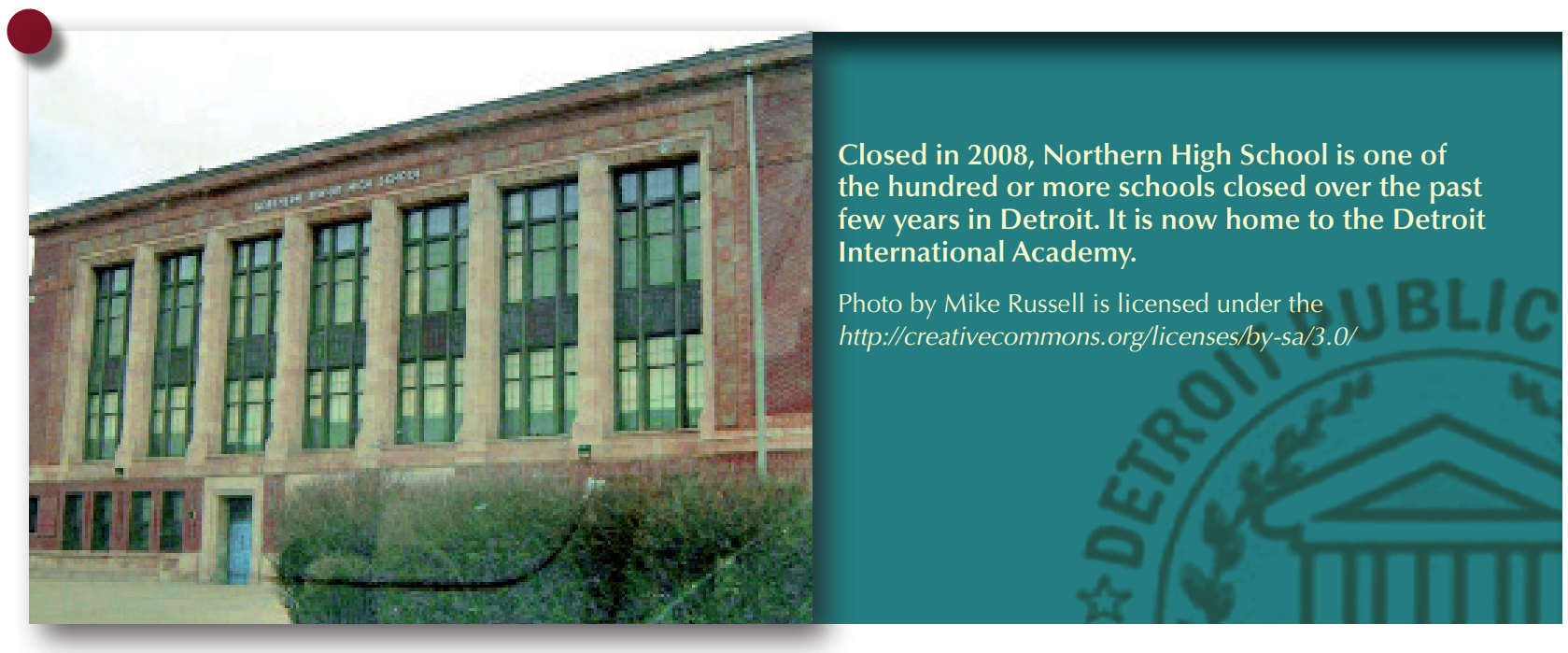




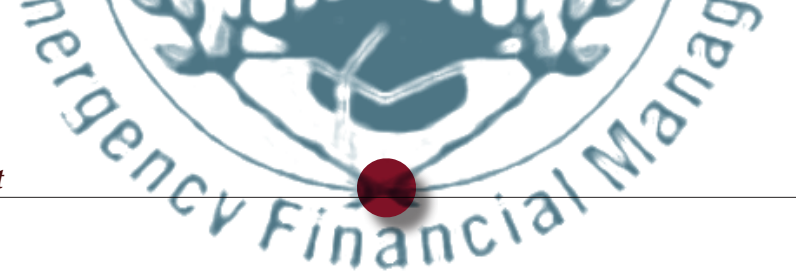

Today, the goal for administrators and facility planners in the DPS is to substantially improve the physical learning environment for its remaining 90000 students and hundreds of teachers. Hopefully, this will be advanced by with a proposal that Detroit voters approved in November 2009. "Proposal S" is a bond which takes advantage of USD 500 million in stimulus dollars that President Barack Obama made available nationwide to build new schools and modernise existing ones. The funds come in the form of no-interest and low-interest bonds made available in part through the American Recovery and Reinvestment Tax Act of 2009, the federal stimulus programme. Under Michigan state law the bond money can only be used for new building construction, remodelling schools and furnishing and equipping schools. The funding cannot be used to pay teacher or administrator salaries, operating expenses or routine facility repairs. ${ }^{1}$ With the resulting funds, Detroit will completely renovate and modernise ten school buildings.

Furthermore, although the District is continuing to close pre-primary, primary and secondary schools, it will also build eight new schools. The schools will include more grade levels, and by combining resources they will reduce overall operating costs. This funding, which must be spent within the next three years, is part of a larger school construction and renovation programme, the Detroit Public Schools Master Facilities Plan. This 5-year plan - covering the period 2010 to 2015 - has identified five priorities: academic rebirth; facility renewal; fiscal responsibility; neighbourhood focus; and safety and security. By creating multi-level school campuses and open use of sports complexes, the facilities plan will not only renovate and rebuild schools, but will contribute to neighbourhood development in Detroit, many of which are desperate need of gentrification.

The projected benefits of the facilities plan seem to outweigh any potential drawbacks. First, the aim is that there will be no tax increase for Detroit residents. Second, according to State of Michigan estimates, it is anticipated that 11000 jobs will be created and Detroit workers will have hiring preference. This will provide a much-needed employment injection in the state with the highest unemployment rate. ${ }^{2}$ Overall, it is estimated that $75 \%$ of the student population will attend new or recently renovated schools, and therefore be directly affected by the facilities plan. Lastly, the District, in co-operation with the local unions and contractors, is developing job training and apprenticeship programmes for students and Detroit workers. One of the plans under development is to create a new construction institute which would give students job development and mentoring opportunities.

While these benefits are appealing to a city in need of revitalisation, many are concerned that this facilities plan will create additional financial problems for the DPS. With a budget deficit of over USD 300 million, critics worry that the District's debt is already too massive to take on any bonds and subsequently deepen the debt. These concerns are not unwarranted.

This is not the first time that school administrators have attempted to tackle physical infrastructure issues. In 1993, the then superintendent proposed a USD 1.5 billion bond to renovate deteriorating schools, which Detroit voters approved in 1994. By 1997, however, ageing school buildings had still not received any funding. As Jeffrey Mirel, an education historian and expert on Detroit schools, points out, "Given the huge amount of money at stake, even assuming a very low rate of inflation, the purchasing power of the bonds was falling by over USD 30 million per year. Not spending the funds was costing money." ${ }^{3}$

1. Citizens Research Council of Michigan (2009), "Detroit Ballot Issues: Proposal S: Detroit Public Schools Bond Proposal", http://www. crcmich.org/PUBLICAT/2000s/2009/memo1095.pdf.

2. Based on United States Bureau of Labor Statistics, www.bls.gov/web/laus/laumstrk.htm.

3. J. Mirel (2004), "There is Still a Long Road to Travel, and Success is Far from Assured", in J.R. Henig and W.C. Rich (eds.), Mayors in the Middle: Politics, Race, and Mayoral Controls of Urban School, Princeton University Press, Princeton, NJ. 
Although improvements to Detroit schools were much needed, the project was never fully realised and turned out to be costly to the school district. The stakes are the same for "Proposal S". If DPS is unable to spend the school construction bonds, it will ultimately lose the funding, which would make an already unstable school system even more volatile.

Detroit is therefore pushing on with its revitalisation plans. Recently, Robert Bobb, the Emergency Financial Manager, announced the closure of 45 schools (out of 172) in the district, citing a citywide population decline, as well as students transferring to alternative school arrangements such as charter and private schools. These closures are projected to save the system millions of dollars in annual expenses through reduced operating and maintenance costs. Meanwhile, DPS is carrying out a thorough school closure process. This includes comprehensive data gathering and public engagement through town hall meetings in order to determine whether schools should be preserved or demolished. There are a number of criteria that administrators and facilities planners are using in their appraisal, including academic performance, demographic trends, facility condition and facility, investment needed and operating costs. Nevertheless, the decision to close these schools is a blow to the community, which has a significant emotional attachment to its schools and the memories they hold.

To prevent mishandling of construction funds, as previously occurred in the 1990s, an oversight committee will be composed of community leaders, parents, business leaders and political officials to ensure accountability. The DPS Bond Advisory and Fiscal Responsibility Committee will be separate from the school board and supervise the construction process and ensure that the objectives of the facilities renewal plan are met on time and within the budget.

As regards the new school buildings themselves, these follow seven planning principles: i) design schools in function of how pupils learn and how educators teach; ii) build flexible, adaptable and sustainable learning environments; iii) support smaller learning environments; iv) develop multi-use facilities that support both community use and local partnerships; v) associate non-traditional spaces (such as museums and parks) with schools in order to broaden curriculum opportunities and make education more relevant; vi) create learning environments that prepare students for further learning and professional life; and vii) create healthy, safe and energy-efficient schools to support the learning environment. ${ }^{4}$

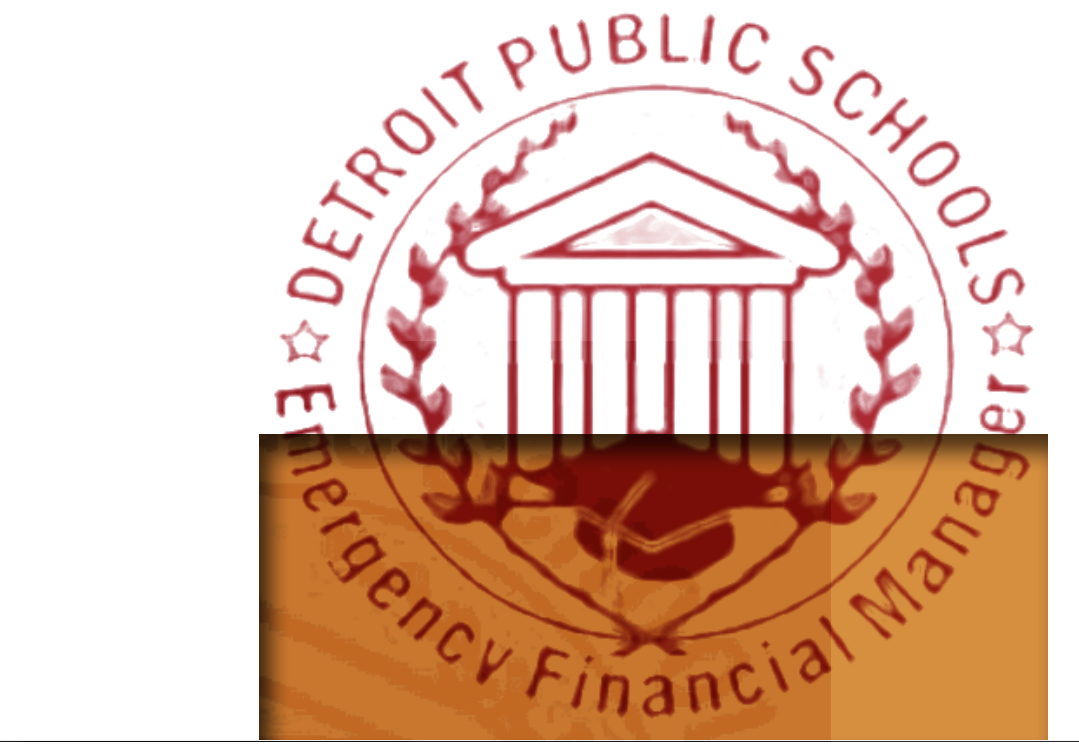

4. Detroit Public Schools (2010), Detroit Public Schools Master Facilities Plan 2010-2015, Office of the Emergency Financial Planner, Detroit. 
Changes to the physical infrastructure will coincide with strategic changes to improve the overall education system in Detroit. With a growing number of schooling alternatives, the push to rebuild and refurbish Detroit public schools will make the latter more competitive and able to retain existing students and attract new ones. The facilities renewal plan will give disadvantaged, urban students an opportunity to learn and achieve in clean and safe $21^{\text {st }}$ century learning environments.

For more information, contact :

Christin Cave

Consultant

Directorate for Education

OECD

2 rue André-Pascal

75116 Paris

France

E-mail: christincave@gmail.com 


\section{ORGANISATION FOR ECONOMIC CO-OPERATION AND DEVELOPMENT}

The OECD is a unique forum where the governments of 31 democracies work together to address the economic, social and environmental challenges of globalisation. The OECD is also at the forefront of efforts to understand and to help governments respond to new developments and concerns, such as corporate governance, the information economy and the challenges of an ageing population. The Organisation provides a setting where governments can compare policy experiences, seek answers to common problems, identify good practice and work to co-ordinate domestic and international policies.

The OECD member countries are: Australia, Austria, Belgium, Canada, the Czech Republic, Chile, Denmark, Finland, France, Germany, Greece, Hungary, Iceland, Ireland, Italy, Japan, Korea, Luxembourg, Mexico, the Netherlands, New Zealand, Norway, Poland, Portugal, the Slovak Republic, Spain, Sweden, Switzerland, Turkey, the United Kingdom and the United States. The Commission of the European Communities takes part in the work of the OECD.

OECD Publishing disseminates widely the results of the Organisation's statistics gathering and research on economic, social and environmental issues, as well as the conventions, guidelines and standards agreed by its members.

This work is published under the responsibility of the Secretary General of the OECD. The opinions expressed and arguments employed herein do not necessarily reflect the official views of the Organisation or of the governments of its member countries.

You can copy, download or print OECD content for your own use, and you can include excerpts from OECD publications, databases and multimedia products in your own documents, presentations, blogs, websites and teaching materials, provided that suitable acknowledgment of OECD as source and copyright owner is given. All requests for public or commercial use and translation rights should be submitted to rights@oecd.org. Requests for permission to photocopy portions of this material for public or commercial use shall be addressed directly to the Copyright Clearance Center (CCC) at info@copyright.com or the Centre français d'exploitation du droi de copie (CFC) contact@cfcopies.com. 